\title{
EFFECT OF ARTEMISIA SANTONICA ON SCHISTOSOMA MANSONI INFECTED MICE: PARASITOLOGIOCAL, HISTOPATHOLOGICAL AND SCANNING ELECTRON MICROSCOPICAL STUDIES
}

By

\author{
HEND M. TAG ${ }^{1,2 *}$, MONA M. HENEDAK ${ }^{3}$, NAHLA H. SALLAM ${ }^{4}$, EHSSAN A. \\ HASSAN ${ }^{5}$, RAWIA A. ZAYED ${ }^{6}$ and SAMAH TALAAT MOHAMMED ${ }^{3}$
}

Department of Biology ${ }^{1}$, Faculty of Sciences and Arts-Khulais, Jeddah University, Jeddah P.O. Box 355, Code 21921, Saudi Arabia; Department of Zoology ${ }^{2}$, Faculty of Sciences, Suez Canal University, Ismailia, Department of Zoology ${ }^{3}$, Faculty of Science, El Arish University, Department of Veterinary Parasitology ${ }^{4}$, Suez Canal University, Ismailia, Egypt; Department of Biology ${ }^{5}$, College of Science and Humanities in Al-Kharj, Prince Sattam Bin Abdulaziz University, Al-Kharj 11942 Saudi Arabia And Department of Pharmacognosy ${ }^{6}$, Faculty of Pharmacy, Zagazig University, Egypt ( ${ }^{*}$ Correspondence: hend_taha@science.suez.edu.eg)

\begin{abstract}
Schistosomiasis is one of the most wide spread tropical diseases. Millions of people suffer severe illness related to schistosomiasis. This study evaluated the anti-parasitic effects of crude Artemisia santonica and their aqueous and hexane fractions against Schistosoma mansoni infected mice by some parasitologiocal and histopathological studies as worm load, liver egg load, intestine egg load, oogram pattern and also by surface ultrastructure of recovered worms using SEM. The result reflected that mice treated with crude extracts of A. santonica and their aqueous fractions gave a promise anti-inflammatory and anti-schistosomal agent.
\end{abstract}

Key words: Artemisia santonica, Schistosoma mansoni, Parasitologic, SEM

\section{Introduction}

Schistosomiasis, a worldwide concern, affects more than 200 million people worldwide, and another 500-779 million people are at risk, especially children (Steinmann $e t$ $a l$, 2006). Globally, it was estimated to cause more than 200,000 deaths per year and at least $90 \%$ of people requiring treatment in Africa (Clements et al, 2009). Among the different known schistosome species, zoonotic Schistosoma mansoni was the most endemic one in Egypt (Helmy et al, 2009). Schistosomiasis was reported in others Arabian Countries as for example Saudi Arabia (Mohammad, 2014), Yemen (Khalil et al, 2018), Sudan (Amin and Abubaker, 2017), and Libya (Amara et al, 2018),

Pathology associated with S. mansoni results primarily from the accumulation of parasite eggs, giving rise to hepatomegaly that may be superseded by extensive liver fibrosis (Gryseels et al, 2006). It has also been shown that the granulomatous inflammatory response to $S$. mansoni eggs entrapped in the liver induces oxidative stress.
Several medications were used in treatment of schistosomiasis including the Praziquantel, Oxamniquine, Metrifonate, Antimonials, Hycanthone and Niridazole (Fahmy et al, 2014).

Current treatment relies on praziquantel (PZQ). But, El-Hawy et al. (1990) among the Egyptian school children with active urinary hematobiasis treated with praziquantel orally $40 \mathrm{mg} / \mathrm{kg}$ b.w. every 6 months, reported adverse reactions as nausea, abdominal colic, vomiting, diarrhea, dizziness, pyrexia and headache. Experimental in mice, praziquantel showed to be a hepatotoxic, genotoxic and carcinogenic drug (Omar et al, 2005). Besides, the PZQ has stage-dependent susceptibility, showed only poor efficacy to the immature schistosome stages (Keiser et al, 2009). Also, many lines of evidence indicated to increasing the emergence of strains of S. mansoni resistant to PZQ (Zhang and Coultas, 2013). So, for controlling schistosomiasis, there was an urgent need to develop a new effective drug. Phytomedicine play a major role in human health care system 
(Panossian, 2014). There is a considerable interest in elucidating the mechanism of their action to develop better medicines. Plants contain many free radical scavenging molecules such as the phenolic compounds, the nitrogen compounds, the vitamins, terpenoids...etc. (Nalini et al, 2015).

In traditional medicine, Artemsia sp. was used for expelling of rheumatism, paralyzing and killing parasites in the digestive tract in addition to controlling their eggs (Mehdi and Farshid, 2015). Artemisia sp. is frequently utilized for the treatment of diseases such as malaria, hepatitis, cancer, inflammation, and infections by bacteria, fungi and viruses (Abad et al, 2012). Recently, some Artemisia species essential oils proved to be friend insecticides for myiasis producing dipterous flies (Bedini et al, 2017), against the stored product insects (Liang et al, 2017) and allopathic chemicals (Gholami et al, 2011). Its compounds are also active towards viral, bacterial and protozoa diseases in vivo and in vitro (Efferth et al, 2011) as well as for cancer therapy (Efferth, 2017).

Generally, a total of 3000 essential oils were recorded, only about 300 of which are significant in the fields of pharmaceutical, agricultural and food (Calo et al, 2015).

The present study aimed to evaluate the antiparasitic effects of Artemisia santonica, and their fractions against Schistosoma mansoni infected mice.

\section{Material and Methods}

Schistosoma mansoni cercariae were purchased from laboratory bred infected $B i$ omphalaria alexandrina in SBSP at TBRI, Giza, Egypt. Following the methodologies as described (Wasilewski et al, 1996). Twenty Albino mice were infected with $S$. mansoni cercariae via the subcutaneous route by $80 \pm 10$ cercariae per mouse (Stirewalt and Dorsey, 1974) and randomly divided into 4 groups ( 5 mice in each cage). The other uninfected 25 mice were randomly divided into 5 groups (Tab. 1).

Selection of animal species: Male Albino mice were used in the study. They were pur- chased from the animal unit from the Schistosome Biological Supply Centre (SBSC), Theodor Bilharz Research Institute (TBRI) where they had been bred under conventional conditions for research purposes. Mice were selected and individually marked. Animals were matched, as closely as possible with an average weight $(20-22 \mathrm{~g})$ in order to reduce the variability of their responses according to guidelines of Organization for Economic Co-operation and Development (OECD, 1998; 2000). All animals were conducted in accordance with the lines Guided for the Care and Use of Laboratory Animals, Institute of Laboratory Animal Resources, National Research Council and in accordance with the guidelines of the international guidelines for animal experimentation.

Housing and feeding conditions: The mice were fed on a standard commercial pelleted diet (El-Kahira Company for Oils and Soap) in an air-conditioned animal house at 20$22^{\circ} \mathrm{C}$, humidity $65 \pm 5 \%$ and light/dark cycles (12/12hrs). The animal experiments were conducted in the animal house at Department of Zoology Faculty of Science, Suez Canal University. Each of the used cages has a card with the data of the experiment.

Preparation of animals: Before use, the selected individual animals were weighed and identified through marks made on their body with permanent ink pens. Mice were housed in plastic cages with stainless steel mesh lids. The animals were kept in their cages for at least 5 days prior to dosing, to allow for their acclimatization to the laboratory conditions. During acclimatization, the animals were observed for ill health or abnormality.

Plants extraction Plant materials were collected from Arish, North Sinai, Egypt, in March 2015 and were identified and authenticated by Department of Botany, Faculty of Science, Suez Canal University on the basis of taxonomic characters and by direct comparison with the herbarium specimens available at the herbarium of Botany department. The plant extract was prepared (Azwanida, 2015) with minor modifications. Briefly, the 
leaves of Artemisia santonica were washed, air-dried and powdered. The dried powder was extracted with $70 \%$ hydro-ethanol solution for $48 \mathrm{~h}$. The marc was further extracted by $70 \%$ hydro-ethanol for $48 \mathrm{~h}$. to obtain the extract. The extract was then filtered and evaporated to dry under reduced pressure on a rotary evaporator (Yamato, Rotary Evaporator, model-RE 801) at the Dewedar's Lab. The yield of crude ethanolic extract of $A$. santonica leaves was found to be $7.1 \& 4 \%$ w/w, respectively

Fractionation of ethanolic plant extract: Ethanol crude extracts from $A$. santonica were partitioned between 2 volumes, then one of them suspended in water $(60 \mathrm{~mL})$. It was extracted with hexane organic solvent by using the separator funnel the residue left in separator funnel was re-extracted twice to separate the aqueous and the hexane fractions of the ethanolic extract then filtered using Whatman No. 41 filter paper to remove particles. Extracts were evaporated to dry under reduced pressure on a rotary evaporator (Yamato, Rotary Evaporator, model-RE 801) at Dewedar's Lab., yield of aqueous and hexane extracts of $A$. santonica leaves were $48.5 \& 20.5 \% \mathrm{w} / \mathrm{w}$, respectively.

Phytochemical screening of plant extracts and its fractions: Air-dried powdered plants materials which collected in flowering stage and $(1 \mathrm{gm})$ of the aqueous \& hexane fractions of both plants were subjected to the steam distillation for volatile oil (Egyptian Pharmacopeia, 1953), carbohydrate and/or glycoside (Trease and Evans, 1978), flavonoids (Mabry et al, 1970), tannins (Balbaa, et al 1976), Saponin (Farnsworth, 1996), alkaloids and/or basic nitrogenous substances and mucilage (Trease and Evans, 1978), sterols and/or triterpenes (Libermann's 1885; Kebede et al, 2015).

Acute toxicity plant extracts study and their fractions in mice: Fifty seven male Albino mice with average weight $(20-22 \mathrm{~g})$ were acclimatized for a week in cleaned cages and randomly divided into 3 groups of 3 animals each for each extract. Gs 1,2 \& 3 were intraperitoneal injected with the crude, aqueous and hexane extracts either for $A$. santonica extracts $(10,100 \& 1000 \mathrm{mg} / \mathrm{kg}$ body/wt) following the method of (Lorke, 1983). The control group was administered saline intraperitoneal. Immediately after dosing, the mice were continuously observed for at least $4 \mathrm{hr}$, and occasionally up to $6 \mathrm{hr}$. They were kept under observation for up to 14 days (frequency of $12 \mathrm{hr} /$ day) for signs of toxicity and mortality.

Parasitological examination: The experimental design was prepared (Tab. 1). The mice were decapitated and underwent portomesentric perfusion for recovery of the adult schistosome worms for the Parasitological examination, which include estimation of worm burden (Smithers and Terry, 1965), calculation of the percentage of immature, mature and dead ova in tissues according to (Pellegrino et al, 1962), Estimation of the egg load by counting number of eggs in infected intestine and liver tissues (Cheever, 1970).

SEM examination was done at Electron Microscopy Unite of Theodor Bilharz Research Institute (Glauert, 1974) to determine the damaging effects on the surface of the treated worms in comparison to the untreated one. The samples were centrifuged then the pellets were immediately processed.

Histopathological examination: Both control \& treated mice groups were anaesthetized and immediately dissected. The tissues of liver were fixed and prepared for histopathological examination (Drury and Wallington, 1980). The size of hepatic granulomas in $S$. mansoni-infected was measured in mice as described by Jacobs et al. (1997).

The classification of evolutionary stages of granulomas was performed according to the previous studies (Costa-Silva et al, 2002; Lins et al, 2008), and for the morphometric analysis. Image J software was measured granuloma diameter using spatial calibration. The process of spatial calibration involves calibrating a single image against known values, then applying that calibration to the 
un-calibrated image, both images are at the same magnification. For each treatment granuloma size were measured and the mean values from 5 mice for each group were used for statistical analysis.

Statistical analysis: Data were tabulated and analyzed using IBM personal computer using SPSS 16 microstate software package. ANOVA (analysis of variance) was used as the test of significance. $P$ value was considered significant if it was $<0.05$ (Field, 2000). Duncan test was used as the multiple comparison tests after obtaining significant result by post-hoc comparison to determine significantly different pair (Abdi et al, 2007).

Ethics: This study was conducted in accordance with the legal ethical guidelines of the Medical Ethical Committee of the National Research Center, Dokki, Egypt (approval no. 09210).

\section{Results}

In the preliminary test (test for primary metabolites) volatile oil, sterols and triterpens were detected in the crude extracts and the hexane fractions of both plants extracts and not detected in their aqueous fractions. Glycoside was detected in the crude extracts and the aqueous fractions of both plants extracts but not detected in their hexane fractions. Notably, tanins, saponins, alkaloids and mucilage were not detected in all tested plant extract (Tab. 2).

Acute toxicity study was conducted in mice weighting 20-22g. The whole plants ethanolic extract, their aqueous and hexane fractions were given by intraperitoneal injection. Initially the animals were administrated with a single dose of $10,100 \mathrm{mg} / \mathrm{kg}$ of body weight and the dose was increased to 1000 mg. All the groups animals $(n=5)$ all animals were observed for clinical signs and preterminal deaths for the first $4 \mathrm{hrs}$ after dose administration on the day of treatment and once daily on days 2 to 14 for changes in skin and fur, eyes, mucous membrane, musculature and respiratory, symptoms. There was no abnormality observation in all groups, all extracts had no significant toxic ef- fect in mice and the plants materials were found to be nontoxic.

Worm burden: The result showed significant differences between the total worm load of mice treated with $A$. santonica or their fractions as compared to the untreated animals (Tab. 3). The treatment with crude and aqueous fractions of $A$. santonica significantly decreased $(\mathrm{P}<0.05)$ the total worm load as compared to the untreated ones and mean values were $(4.26 \pm 0.40 \& 4.13 \pm 0.50)$ for crude and aqueous fractions of $A$. santonica respectively. Worm reduction rates for the treated groups with crude, aqueous and hexane A. santonica were $(32 \%, 24 \%$ and $20 \%$ respectively), the highest reduction rates in the number of paired worms were also recorded in the treated groups with crude, aqueous and hexane A. santonica (50\%, $79.25 \& 35 \%$, respectively). Also, the highest reduction rates in the number of single worms were recorded in the treated groups comparing to untreated one. Crude extract, aqueous and hexane fractions of $A$. santonica, significantly affect the worm burden with a reduction rate of $160 \%, 230 \%$ \& $100 \%$, respectively.

Oogram study: showed the percentage of the different developmental stages of $S$. mansoni eggs. The immature ova of treated groups with crude extracts and aqueous fractions of plants showed significant differences $(\mathrm{P}<0.05) \quad(71.2 \pm 3.07 \& 88.20 \pm 1.02$, respectively). Similarly, significant reductions were found $(\mathrm{P}<0.05)$ in the mature ova in same treated groups with aqueous frac-

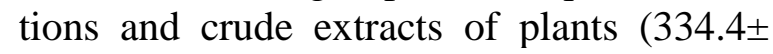
$24.75 \& 443.60 \pm 31.66$ respectively) as compared to the untreated group. There were significant (Tab. 4) increase $(\mathrm{P}<0.05)$ in numbers of dead ova in groups treated with the crude extracts and the aqueous fraction of the plants as compared to untreated group (5.20 $\pm 0.48 \& 7.00 \pm 0.44$ respectively)

Tissue egg load in intestine and liver: Effect of crude A. santonica and their fractions on the worm ability for oviposition was assessed by counting $S$. mansoni eggs/g ret- 
ained in both intestine and liver tissues (Tab. 4). As to egg load in intestine tissue, significant reductions were recorded in the mean number of eggs/g intestine in groups treated with the aqueous, crude extracts and hexane fractions of the plants $(2.20 \pm 0.40,4.40 \pm$ $1.50 \& 9.26 \pm 4.56$, respectively) when compared to untreated one $(24.05 \pm 6.10)$ ( $\mathrm{P}<$ $0.05)$. As to liver egg load, significant reductions were recorded in mean number of eggs/g liver in infected mice treated with the crude and aqueous and hexane fractions of A. santonica $(1.50 \pm 0.14 \& 1.70 \pm 0.7$ respectively) compared to the untreated infected group $(9.50 \pm 3.60) \quad(\mathrm{P}<0.05)$.

SEM: After treatment with crude A. santonica extract, the adult male worms showed obvious swelling in the anterior part of the tegument in addition, pronounced alterations in gynaecophoric canal (Fig. 1A) collapsed and reduced tubercles with shortened or diminished spines (Fig. 1B). Furthermore, vesicles were near damaged tubercles (Fig. 1C), while after aqueous fraction treatment showing mild to severe obvious collapsed and reduced tubercles with shortened or diminished spines. Pronounced alterations, peeling in tegument and ruptured tubercles pronounced vesicles were near damaged tubercles (Figs. 2A \& B), and to hexane treatment Adult males showed pronounced alterations in tegument in terms of swelling of worm anterior part, wrinkling and pronounced vesicles, generally collapsed and reduced tubercles with shortened or diminished spines (Figs. 2C \& D).

Histopathological studies: After 8 weeks post infection, liver of infected mice treated with the crude $A$. santonica extract showed normal hepatocytes away from granulomas (Fig. 3A). In granulomatous areas hydropic degeneration was recorded. Dark brown pigment wasn't observed. Kupffer cells were minor than those of untreated infected ones, with narrowed sinusoids exudative-productive granuloma (Fig. 3B). Liver of mice treated with aqueous fraction showed pre-granulomatous exudative lesions were common with less fibrotic granulomas (Figs. 3C \& D) and foreign body, lesser hydropic degeneration as compared with untreated infected mice, also narrowed sinusoids, Kupffer cells were minor than those of untreated infected group. Liver at this dose showed minor pyknotic hepatocytes near granulomas; dark brown pigmentation was minor or not observed totally in some mice. With hexane fraction extract caused productive granuloma (Fig. 4A). Exudative productive granuloma stages (Fig. 4B). Pregranulomatous stages of granuloma, liver at this dose showed minor pyknotic hepatocytes near granulomas, dark brown pigmentation minor or not seen in some mice and kupffer cells hyperplasia near granulomas.

Measuring hepatic granulomas size: Granulomas diameter was assessed in livers of untreated infected mice and infected treated mice after 8 weeks post infection showed different diameters among different groups (Tab. 5). Granulomas diameter showed highly significant differences $(\mathrm{P}<0.05)$ between untreated infected group $(645.01 \pm 67.86)$ and those treated with crude extracts, aqueous fractions \& hexane fraction $(451.33 \pm 20.26$, $363.33 \pm 15.07 \& 446.66 \pm 94.98$, respectively). Details were given in tables $(1,2,3,4$ \& $5)$ and in figures $(1,2 \& 3)$.

Table 1: Experimental groups design

\begin{tabular}{|l|l|}
\hline G1 & negative control group \\
\hline G2 & Uninfected and treated with A. santonica ethanolic extract $(200 \mathrm{mg} / \mathrm{kg}$,), intraperitoneal (i.p.)daily. \\
\hline G3 & Uninfected and treated with A. santonica aqueous extract $(200 \mathrm{mg} / \mathrm{kg}$,$) , intraperitoneal (i.p.) daily.$ \\
\hline G4 & Uninfected and treated with A. santonica hexane extract $(40 \mathrm{mg} / \mathrm{kg}$,$) , intraperitoneal (i.p.) daily.$ \\
\hline G5 & Infected and untreated \\
\hline G6 & Infected and treated with A. santonica ethanolic extract $(200 \mathrm{mg} / \mathrm{kg}$,$) , intraperitoneal (i.p.) daily.$ \\
\hline G7 & Infected and treated with A. santonica aqueous extract $(200 \mathrm{mg} / \mathrm{kg}$,$) , intraperitoneal (i.p.) daily.$ \\
\hline G8 & Infected and treated with A. santonica hexane extract $(40 \mathrm{mg} / \mathrm{kg}$,$) , intraperitoneal (i.p.) daily.$ \\
\hline G9 & Uninfected mice treated with DMSO solution $(10 \mathrm{mg} / \mathrm{kg}$,$) , intraperitoneal (i.p.) daily.$ \\
\hline
\end{tabular}


Table 2: Phytochemical analysis of crude, aqueous and hexane A. santonica leaf extract

\begin{tabular}{|l|c|c|c|}
\hline Test & Crude & Aqueous & Hexane \\
\hline Volatile oil & + & - & + \\
\hline Glycoside & + & + & - \\
\hline Flavonoids & + & + & - \\
\hline Tannins & - & - & - \\
\hline Saponin & - & - & - \\
\hline Alkaloids & - & - & - \\
\hline Mucilage & - & - & - \\
\hline Sterols and triterpenes. & + & - & + \\
\hline
\end{tabular}

$+=$ indicates presence $\quad-=$ indicates absent

Table 3: Worm burden in S. mansoni infected mice treated with A. santonica and its fractions after 8 weeks post-infection.

\begin{tabular}{|l|c|c|c|c|c|c|}
\hline \multirow{2}{*}{ Groups } & \multicolumn{3}{|c|}{ Mean worm burden } & \% Re- & Total worm & Worm \% \\
burden & Paction & reduction \\
\cline { 2 - 6 } & Single & \% Reduction & Paired & & $5.00 \pm 0.10$ & \\
\hline Infected non-treated & $1.00 \pm 0.53$ & & $4.00 \pm 1.5$ & & $4.26^{*} \pm 0.40$ & 32 \\
\hline Infected +AT crude extract & $2.26^{*} \pm 1.20$ & 160 & $2.00^{*} \pm 1.00$ & 50 & 24 \\
\hline Infected+AT aqueous extract & $3.30^{*} \pm 1.40$ & 230 & $0.83^{*} \pm 0.47$ & 79.25 & $4.13^{*} \pm 0.50$ & 24 \\
\hline Infected +AT hexane extract & $2.00^{*} \pm 1.40$ & 100 & $2.6^{*} \pm 0.66$ & 35 & $4.60 \pm 1.00$ & 20 \\
\hline
\end{tabular}

Values means \pm SE. $n=6$, One Way ANOVA followed by Values means \pm SE. $n=6$, One Way ANOVA followed by Duncan multiple comparison tests * $\mathrm{p}<0.05$ compared with $S$. mansoni infected mice.

Table 4: Effect of crude A. santonica and its fractions on oogram \& tissue egg load, 8 weeks post-infection.

\begin{tabular}{|c|c|c|c|c|c|c|c|c|}
\hline Groups & \multicolumn{6}{|c|}{ Oogram } & \multicolumn{2}{|c|}{ Egg load } \\
\hline & Mature & $\begin{array}{c}\text { Change } \\
\%\end{array}$ & Immature & $\begin{array}{c}\text { Change } \\
\%\end{array}$ & Dead & $\begin{array}{c}\text { Change } \\
\%\end{array}$ & Liver & Intestine \\
\hline $\begin{array}{l}\text { Infected non- } \\
\text { treated }\end{array}$ & $\begin{array}{c}681.60 \pm \\
56.85\end{array}$ & & $\begin{array}{c}40.60 \pm \\
3.14\end{array}$ & & $\begin{array}{l}1.80 \pm \\
0.48\end{array}$ & & $\begin{array}{c}9.50 \pm \\
3.60\end{array}$ & $\begin{array}{l}24.05 \pm \\
6.10\end{array}$ \\
\hline $\begin{array}{l}\text { Infected + AT } \\
\text { crude extract }\end{array}$ & $\begin{array}{l}443.60 \pm \\
31.66^{*}\end{array}$ & +51 & $\begin{array}{l}71.20 \pm \\
3.07^{*}\end{array}$ & -117 & $\begin{array}{l}5.20 \pm \\
0.48^{*}\end{array}$ & -128 & $\begin{array}{c}1.40 \\
\pm 0.46^{*}\end{array}$ & $\begin{array}{l}4.40 \pm \\
1.50^{*}\end{array}$ \\
\hline $\begin{array}{l}\text { Infected+ AT } \\
\text { aqueous extract }\end{array}$ & $\begin{array}{l}334.40 \pm \\
24.75^{*}\end{array}$ & +35 & $\begin{array}{l}88.20 \pm \\
1.02^{*}\end{array}$ & 11.3 & $\begin{array}{l}7.00 \pm \\
0.44^{*}\end{array}$ & -55.5 & $\begin{array}{l}1.50 \pm \\
0.14^{*}\end{array}$ & $\begin{array}{c}2.20 \pm \\
0.40^{*}\end{array}$ \\
\hline $\begin{array}{l}\text { Infected + AT } \\
\text { hexane }\end{array}$ & $\begin{array}{c}511.80 \pm \\
52.59\end{array}$ & +25 & $\begin{array}{c}36.0 \pm \\
1.67\end{array}$ & 11.3 & $\begin{array}{c}0.80 \pm \\
0.20\end{array}$ & 55.5 & $\begin{array}{l}1.70 \pm \\
0.70^{*}\end{array}$ & $\begin{array}{l}9.26 \pm \\
4.56\end{array}$ \\
\hline
\end{tabular}

Table 5: Differences in hepatic granulomas mean diameter $(\mu \mathrm{m} \pm \mathrm{SE})$ in the liver of $S$. mansoni infected mice treated with crude $A$. santonica and their fractions after 8 weeks post-infection.

\begin{tabular}{|l|c|}
\hline \multicolumn{1}{|c|}{ Groups } & Granuloma size $(\mu \mathrm{m} \pm \mathrm{SE})$ \\
\hline Infected non-treated & $645.01 \pm 67.86$ \\
\hline Infected +AT crude extract & $451.33 \pm 20.26^{*}$ \\
\hline Infected+AT aqueous extract & $363.33 \pm 15.07^{*}$ \\
\hline Infected +AT hexane extract & $446.66 \pm 94.98^{*}$ \\
\hline
\end{tabular}

\section{Discussion}

Egypt is considered one of the highest countries in schistosome's infection rates in the world (Barakat, 2013). Chemotherapy plays a very important role in reducing mortality in highly infected areas. However, recent drug-resistance strains of schistosomes have been recorded (Li et al, 2011; Huang et $a l$, 2012). Results of phytochemical screening tests in the present study showed that the main constituent of crude, aqueous and hexane extracts of $A$. santonica was glycosides, flavonoids and triterpenes (Badae et al, 2017).
Also, the present results agreed with Alwahibi et al. (2016) who reported that natural products Flavonoids isolated from the bark Artemisia species exhibited promising growth inhibitory action of some cancer cells displayed an antioxidant activity. Ferreira (2009) reported that Artemisia sp. have high content of flavonoid and phenolic compounds that are associated with their high antioxidant capacity. The present results showed a significant decrease in the paired worms' burden and increase the single worms' burden in all treated groups, indicating that A. santonica crude extracts and their 
fractions negatively affected the coupling of the worms.

In the present study, the oogram pattern showed significant reduction in the number of viable mature eggs at groups treated with the crude and aqueous extracts of $A$. santonica while hexane fraction didn't affect number of either mature and immature eggs. The number of immature ova increased in groups treated with the crude and aqueous extracts of $A$. santonica, while there wasn't any significant difference in groups treated with the hexane fraction when compared with untreated infected mice. This reduction in viable egg numbers may be to the death of adult worms. The number of dead ova increased in groups treated with the crude and aqueous extracts of A. santonica while there wasn't a significant difference in groups treated with the hexane fraction compared with untreated infected mice. Such changes indicate possible lethal effect of the crude and aqueous extracts of $A$. santonica on released eggs in the lumen of the intestines. Concerning effect of crude extract and their fractions on egg load in the liver and intestine tissues, there were reductions in egg count in these tissues. It is clear from the results that there was the suppression of egg-laying capacity, which may be attributed to a reduced worm burden and/or the extracts may affect the ability of the worms to copulate, thereby affecting egg production by females (AbdelGhaffar, 2004; Zhang et al, 2009; Rabia et $a l, 2010)$. Moreover, other factors may also explain such reduction in schistosomal egg count. These factors are a probable diminished fecundity of the worm pairs and an increased rate of egg excretion due to the egg death (Riad et al, 2009).

The anti-schistosomal activity of the treated groups of $A$. santonica and their fractions was assessed by the SEM studies of the ultrastructure of schistosome tegument. The results showed alteration in male worm tegument including tubercles collapsing, tubercles with reduced spines, tegument swelling or tearing and presences of vesicles. These changes confirm the anti-schistosomal activities of treated groups of $A$. santonica and their fractions, as vesicle formation was indicator of stress and swelling of tegument and focal lysis of worm muscles (Manneck et al, 2011; Zhang et al, 2009). This agreed with Frezza et al. (2013) who pointed out that treatment of mice experimentally infected with $500 \mathrm{mg} / \mathrm{kg}$ of $A$. аnnua, showed significant erosion, peeling, sensory structure damage, and vesicle formation on the tegument of S. mansoni 30 days post-infection. Moreover, worm tegument tearing increases antigen exposure on worm surface to host immune system that result subsequently in worm death (Brindley et al, 1989; Soliman and Ibrahim, 2005).

Granuloma formation and fibrosis are the major causes of morbidity and mortality in association with schistosomiasis (Melo et al, 2011). Where, killing eggs by granuloma inhibit its maturation and lead to damage of its embryo rich in immunopathologic antigens (Lin et al, 2003). Zuim et al. (2012) reported that the greater number of eggs and worms the more number of granulomas are recorded in tissues. Such low granulomas intensities in this study indicate low number of eggs per liver and consequently less severe pathological responses.

In the current results, after 8 weeks post infection most granulomas were in the exudative-productive and productive stages for both untreated infected mice and infected treated mice. These results agreed with Lenzi et al. (2006). Also, the untreated infected mice showed heavy chronic inflammatory infiltration at portal areas that considered an important factor in the development of severe schistosomiasis forms, this result agreed with Zuim et al. (2012). The intensity of schistosomal infection increased the degree of liver fibrosis and granulomatous reaction (El-Lakkany et al, 2004). This agreed with the present histopathological results of infected untreated mice liver, which showed an increased granuloma diameter, total infection area and extensive fibrous tissue ac- 
cumulation. The present study showed that the crude $A$. santonica extracts and their aqueous fractions to infect mice showed less pathological features than untreated ones. The hepatocellular necrosis and hemorrhage diminished greatly around granulomas area. Granuloma size is the most variable frequently used to evaluate the immunopathogenesis of schistosomiasis (Shaha et al, 2017). Granuloma size was controlled by many immune factors related to the egg persistence in lesion and ability of host cells to destroy antigens (Zuim et al, 2012).

In the present study, size of hepatic granulomas in infected mice treated with all extracts showed a significant decrease as compared with untreated infected mice. Variation in activity of different extracts might be due to different nature and amount of active components released with the extraction processes solvent (Mansour et al, 2002).

The present study showed that crude and aqueous extracts of $A$. santonica were effective in reducing worm burden and egg count compared with untreated infected mice, indicating its useful antischistosomal action. Doenhoff et al. (2002) and El Ridi and Tallima (2013) showed that the death of worms after treatment with antischistosomal drugs due to metabolic disorders, mechanical destruction or muscular contraction of them. Moreover, antioxidant supplementation supported the immune response through the antioxidative mechanisms, reduced infectious morbidity and protected from pathogens (Actor et al, 2009). Aly et al. (2007) reported that the importance of antioxidants in the treatment of schistosomal infection and the reduction of worm load as well as ova count.

In the present study, A. santonica and its' aqueous fractions have anti-schistosomal efficacy. Soliman et al. (2007), Abd-Alla et al. (2007); Mehdi and Farshid (2015) found that low concentration of crude A. santonica had anti-inflammatory and antioxidant properties due to flavonoids, triterpenoids, glycoside and steroids.

\section{Conclusion}

The mice treated with crude extracts of $A$. santonica and their aqueous fractions gave a promise anti-inflammatory and anti-schistosomal actions, and safe in animal model. Whereas they improve the alterations of hematological, biochemical, antioxidants parameters in S. mansoni infected mice.

Future studies must determine suitable dosage, synergistic effects, and isolation of active compound in all extracts and to clarify mechanism of action. It was recommended to use a cocktail of plant's crude and aqueous extracts to increase for complete elimination of worms and to improve host antiinflammatory and antioxidant properties.

\section{References}

Abad, MJ, Bedoya, LM, Apaza, L Bermejo, P, 2012: The Artemisia L. Genus: A review of bioactive essential oils. Molec. 25, 3:42-66.

Abd-Alla, OAM, Ghattas, MW, Ahmed HA, 2007: Immunopathological studies on some meicinal plants used as antiparasitics agent SCVM J, 12:2-8.

Abdel-Ghaffar, O, 2004: Assessment of the efficacy of Ro 16-2308 against the Egyptian strain of $S$. mansoni in mice: Parasitological, hematological and biochemical criteria Egypt. J. Zool. 42:173-203.

Abdi, H, Bonferroni, A, Sidak, Z, 2007: Corrections for multiple comparisons. In: Sal-kind, NJ, editor: Encyclopedia of Measurement and Statistics. Thousand Oaks, CA, USA.

Actor, JK, Hwang, SA, Kruzel, ML, 2009: Lactoferrin as a natural immune modulator. Curr. Pharm. Des. 15, 17:1956-73.

Alwahibi, LH, Abdel-Mageed, WM, Abdelkader, MS, Bayoumi, SA, Basudan, OA, El-Gamal, AA, et al, 2016: Sesquiterpene lactones and flavonoids from Artemisia sieberi. IJPPR 8, 4:639-44.

Aly, HF, Mantawy, MM, 2013: Efficiency of ginger (Zingbar officinale) against Schistosoma mansoni infection during host-parasite association. Parasitol. Int. 62, 4:380-9.

Amara, RO, Ramadan, AA, El-Moslemany, R M, Eissa, MM, ElAzzouni, MZ, et al, 2018: $\mathrm{Pr}-$ aziquantel-lipid nanocapsules: an oral nanotherapeutic with potential Schistosoma mansoni tegumental targeting. Int. J. Nanomed. 13:4493-505 
Amin, M, Abubaker, H, 2017: Control of schistosomiasis in the Gezira irrigation scheme, Sudan. J. Biosoc. Sci. 49, 1:83-98

Azwanida, NN, 2015: A review on the extraction methods use in medicinal plants: Principle, strength and limitation. Med. Aromat. Plants 4: 1-6.

Badea, ML, Dobrescu, A, Delian, E, Pădure, I M, Bădulescu, L, 2017: Chemical constituents of the essential oil of Artemisia santonica L (Asteraceae) ecotypes from Romania. Sci. PapersSeries B-Horticulture 61:451-4.

Balbaa, S, Hilal, S, Zaki, A, 1976: Medicinal Plant Constituent. $2^{\text {nd }}$ edition. Cairo University Press, Egypt.

Barakat, RM, 2013: Epidemiology of schistosomiasis in Egypt: Travel through time. J. Adv. Res. 4:425-32.

Bedini, S, Flamini, G, Cosci, F, Ascrizzi, R, Echeverria, MC, et al, 2017: Artemisia spp. essential oils against the disease-carrying blowfly Calliphora vomitoria. Parasit. Vectors 10, 1:806.

Brindley, PJ, Strand, M, Norden, AP, Sher, A, 1989: Role of host antibody in the chemotherapeutic action of praziquantel against Schistosoma mansoni: Identification of target antigens. Mol. Biochem. Parasitol. 34, 2:99-108.

Calo, JR, Crandall, PG, O'Bryan, CA, Ricke, SC, 2015: Essential oils as antimicrobials in food systems: A review. Food Control 54:111-9.

Cheever, W, 1986: The intensity of experimental schistosome infections modulates hepatic pathology. Am. J. Trop. Med. Hyg. 35:124-33.

Clements, AC, Firth, S, Dembele, R, Garba,

A, Toure, S, et al, 2009: Use of Bayesian geo statistical prediction to estimate local variations in Schistosoma haematobium infection in Western Africa. Bull. WHO 87:921e9

Costa-Silva, M, Rodrigues-Silva, R, Hulstijn, M, Neves RH, Panasco, M, et al, 2002: Natural Schistosoma mansoni infection in Nectomys squamipes: Histopathological and morphometric analysis in comparison to experimentally infected $N$. squamipes and $\mathrm{C} 3 \mathrm{H} / \mathrm{He}$ mice. Mem. Inst. Oswaldo Cruz 97, 1:S129-42.

Doenhoff, MJ, Kusel, JR, Coles, GC, Cioli, D, 2002: Resistance of Schistosoma mansoni to praziquantel: is there a problem? Trans. R. Soc. Trop. Med. Hyg. 96, 5:465-9.

Drury, RB, Wallington, EA, 1980: Carleton's Histological Technique. Oxford University Press, England
Efferth, TH, 2017: From ancient herb to modern drug: Artemisia annua and artemisinin for cancer therapy. Semin. Cancer Biol. 46: 65-83.

Efferth, TH, Florian, T, Ahmed, WM, 2011: Cytotoxic activity of secondary metabolites derived from Artemisia annua L. towards cancer cells in comparison to its designated active constituent Artemisinin. Phytomed. 18:959-69.

Egyptian Pharmacopeia, 1953: English text. Cairo University Press, Egypt

El-Hawey, AM, Massoud, AM, el-Rakieby, A, Rozeik, MS, Nassar, MO, 1990: Side effects of praziquantel in bilharzial children on a field level. J. Egypt. Soc. Parasitol. 20, 2:599-605

El-Lakkany, NM, El-Din, SHS, Sabra, AA, Hammam, OA, 2011: Pharmacodynamics of mefloquine and praziquantel combination therapy in mice harboring juvenile and adult Schistosoma mansoni. Mem. Inst. Oswaldo Cruz 106:814-822

El Ridi, RAF, Tallima, HAM, 2013: Novel therapeutic and prevention approaches for schistosomiasis: Review. J Adv. Res. 4, 5:467-78. Fahmy, RS, Ibrahim, R, Mansour, EM, 2014: The potential role of mefloquine against Schistosoma mansoni infection by prohibition of the hepatic oxidative stress in mice. JOBAZ 67:40-7.

Farnsworth, NR, 1996: Phytochemical screening of the biologically active compounds from higher plants. J. Pharm. Sci. 55:227-56.

Ferreira, JF, 2009: Artemisia species in small ruminant production: Their potential antioxidant and anthelmintic effects. In: Appalachian Workshop and Research Update: Improving Small Ruminant Grazing Practices, 53-70. Mountain State University/USDA: Beaver, WV, USA. Frezza, TF, Fernandes de Oliveira, CN, Banin, TM, 2013: Tegumentary changes in two different strains of Schistosoma mansoni treated with artemisinin and artesunic acid. Rev. Pathol. Trop. 42:309-21.

Gholami, BA, Faravani, M, Kashki, MT, 2011: Allelopathic effects of aqueous extract from Artemisia kopetdaghensis and Satureja hortensison growth and seed germination of weeds. J. Appl. Environ. Biol. Sci. 1, 9:283-90.

Gryseels, B, Polman, K, Clerinx, J, Kestens, L, 2006: Human schistosomiasis. Lancet 368: 1106-18.

Helmy, M, Mahmoud, S, Fahmy, Z, 2009: Schistosoma mansoni: Effect of dietary zinc supplement on egg granuloma in Swiss mice treated with praziquantel. Exp. Parasitol. 122:310-7. 
Huang, HH, Rigouin, C, Williams, DL, 2012: The redox biology of schistosome parasites and applications for drug development. Curr. Pharm. Dis. 18, 24:3595-611.

Jacobs, W, Bogers, J, Deelder, A, Wéry, M, Van Marck, E, 1997: Adult Schistosoma mansoni worms positively modulate soluble egg antigen-induced inflammatory hepatic granuloma formation in vivo: Stereological analysis and immunophenotyping of extracellular matrix proteins, adhesion molecules, and chemokines. Am. J. Pathol. 150, 6:2033-45.

Kebede, T, Kibret, F, Fikre, M, Milkyas, E, 2015: Phytochemical screening and characterization of olean-18-ene type triterpeniod from the roots of Lantana camara. Sci. Technol. Arts. Res. J. 4, 1:91-4.

Keiser, J, Chollet, J, Xiao, S, Mei, J, Jiao, P, et al, 2009: Mefloquine: An amino alcohol with promising antischistosomal properties in mice.

PLoS. Negl. Trop. Dis. 3, 1:e350.

Khalil, HHM, Morsy, ATA, Abdel Gawad, M I, 2018: Yemen, a risky focus for endemics, epidemics and pandemics. J. Egypt. Soc. Parasitol. 48, 2:481-2

Lenzi, M, Matos, JZ, Orth, AI, 2006: Variação morfológica e reprodutiva de Aechmea lindenii (E. morren) Baker var. lindenii (Bro-meliaceae). Acta Bot. Brasil. 20, 2: 487-500.

Li, HJ, Liang, YS, Dai, JR, Wang, W, Qu, G L, et al, 2011: Studies on resistance of Schistosoma species to praziquantel XIV experimental comparison of susceptibility to praziquantel between PZQ-resistant isolates and PZQ-susceptible isolates of Schistosoma japonicum in stages of adult worms, miracidia and cercariae. Chinese nese J. Schist. Cont. 23, 6:611-9.

Liang, JY, Wang, WT, Zheng, YF, Zhang, D, Wang, JL, et al, 2017: Bioactivities and chemical constituents of essential oil extracted from Artemisia anethoides against two stored product insects. J. Oleo. Sci. 66, 1:71-6.

Liebermann, C, 1885: Ueber das Oxychinoterpen. Chem. Ber. 18:1803-9.

Lin, DD, Liu, YM, Hu, F, Zhang, SJ, 2003: Animal host of Schistosoma japonicum and transmission of schistosomiasis in Poyang lake region. J. Trop. Med. 3:383-7.

Lins, RA, Cavalcanti, CB, Araujo-Filho, JL, Melo-Junior, MR, Chaves, ME, 2008: Distribution of eosinophils at different stages of hepatic granuloma evolution in the mice infected with
Schistosoma mansoni. Rev. Soc. Brasil. Med. Trop. 41, 2:173-8.

Lorke, DA, 1983: new approach to practical acute toxicity testing. Arch. Toxicol. 54:275-87.

Mabry, I, Markham, K, Thomas, M, 1970: Systematic Identification of Flavonoids. Springer-Verlage, New York, Heidelberg, Berlin.

Manneck, T, Braissant, O, Ellis, W, Keiser J, 2011: Schistosoma mansoni: Antischistosomal activity of the four optical isomers and the two race-mates of mefloquine on schistosomula and adult worms in vitro and in vivo. Exp. Parasitol. 127: 260-9.

Mansour, S, Ibrahim, A, Abdel-Hamid, H, 2002: Botanical biocides, 8 . Impact of some plant extracts on Biomphalaria alexandrina snails and on Schistosoma mansoni miracidia and cercariae. Egypt. J. Schist. Infect. Dis. 24:81-99.

Mehdi H, Farshid, K, 2015: Antimicrobial effects of Artemisia santonica. Adv. Herb. Med. 1, 4:43-6.

Melo, GL, Sponchiado, J, Machado, AF, Caceres, NC, 2011: Small-mammal community structure in a South American deciduous Atlantic Forest. Commun. Ecol. 12:58-66.

Mohammad, KA, 2014: Prevalence of schistosomiasis in Al-Baha Province, Saudi Arabia in years 2012 \& 2013 (prospective \& comparative study). J. Egypt. Soc. Parasitol. 44, 2:397-404.

Nalini, MS, Akshath, JV, Prakash, HS, 2015: Antioxidative and $\alpha$-amylase inhibitory potentials of medicinal plants from the Western Ghats of Southern India. Pharm. Let. 8:18-25.

Omar, A, Elmesallamy, Gel-S, Eassa, S, 2005: Comparative study of the hepatotoxic, genotoxic and carcinogenic effects of praziquantel distocide $\&$ the natural myrrh extract mirazid on adult male Albino rats. J. Egypt. Soc. Parasitol. 35, 1: 313-29.

Panossian, A, 2014: Phytomedicine, Editorial. Phytomedicine 21, 7:927.

Pellegrino, J, Oliveira, CA, Faria, J, Cunha, AS, 1962: New approach to screening of drugs in experimental Schistosoma mansoni in mice. Am. J. Trop. Med. Hyg. 11:201-15.

Rabia, F, Nagy, E, Aly, A, Mohamed, F, ElAssal, A, et al, 2010: Effect of treatment with antifibrotic drugs in combination with PZQ in immunized Schistosoma mansoni infected murine model. J. Am. Sci. 6, 5:208-16.

Riad, NH, Taha, HA, Mahmoud, YI, 2009: Effects of garlic on albino mice experimentally infected with Schistosoma mansoni: A parasito- 
logical and ultrastructural study. Trop. Biomed. 26, 1:40-50.

Shaha, KK, Bobbi, P, Mariam, A, 2017: Histopathologic review of granulomatous inflammation. J. Clin. Tubercul. Mycobact. Dis. 7:1-12.

Smithers, SR, Terry, RJP, 1965: Infection of laboratory hosts with cercariae of Schistosoma mansoni and the recovery of adult worms. Para sitology 55:695-700.

Soliman, MFM, Ibrahim, MM, 2005: Antischistosomal action of atorvastatin alone and concurrently with medroxyprogesterone acetate on Schistosoma haematobium harbored in hamster: Surface ultrastructure and parasitological study. Acta Trop. 93, 1:1-9.

Soliman, MFM, Yousif, MF, Zaghloul, SS, Okba, MM, 2007: Seasonal variation in the essential oil composition of Origanum majorana L. cultivated in Egypt. Z Naturforsch C. 64, 9/10: 611-4

Steinmann, P, Keiser, J, Bos, R, Tanner, M, Utzinger, J, 2006: Schistosomiasis and water resources development: Systematic review, me- ta-analysis, and estimates of people at risk. Lancet Infect. Dis. 6:411-25.

Stirewalt, MA, Dorsey, CH, 1974: Schistosoma mansoni: Cercarial penetration of host epidermis at the ultrastructural level. Exp. Parasitol. 35:115.

Trease, G, Evans, WC, 1978: A Text Book of Pharmacognosy. $2^{\text {nd }}$ Ed, Baillier Tindal, London. Zhang, CW, Xiao, SH, Utzinger, J, Chollet, J, Keiser, J, et al, 2009: Histopathological changes in adult Schistosoma japonicum harbored in mice treated with a single dose of mefloquine. Parasitol. Res. 104, 6:1407-16.

Zhang, S, Coultas, KA, 2013: Identification of plumbagin and sanguinarine as effective chemotherapeutic agents for treatment of schistosomiasis. Int. J. Parasitol. Drugs Drug Resist. 3:28-34. Zuim, NRB, Allegretto, SM, Linares, AX, Magalhaes, LA, Zanotti-Magalhaes, EM, 2012: A study of the granulomatous responses induced by different strains of Schistosoma mansoni. Interdiscip. Perspect. Infect. Dis. 9, 1:1-8.

\section{Explanation of figures}

Fig. 1: SEM (A) Schistosoma mansoni couple after exposure to crude A. santonica, (B) and (C) S. mansoni after exposure to crude A. santonica extract

Fig. 2: SEM (A \& B) male S. mansoni after exposure to aqueous fraction of A. santonica, (C \& D) male S. mansoni after exposure to hexane fraction of A. santonica.

Fig. 3: Light micrograph of liver of S. mansoni infected mouse H\&E (A) treated with crude A. santonica extract (100x), (B) treated with crude A. santonica extract (400x), (C) treated with aqueous fraction of A. santonica extract Magnification (200x), (D) treated with aqueous fraction of A. santonica extract (100x).

Fig. 4: (A) Light micrograph of liver of S. mansoni infected mouse treated with hexane fraction of A. A. santonica extract H\&E. Magnification (400x), (B) and (C) Light micrograph of liver of S. mansoni infected mouse treated with hexane fraction (100x), (C): H\&E. (100x).
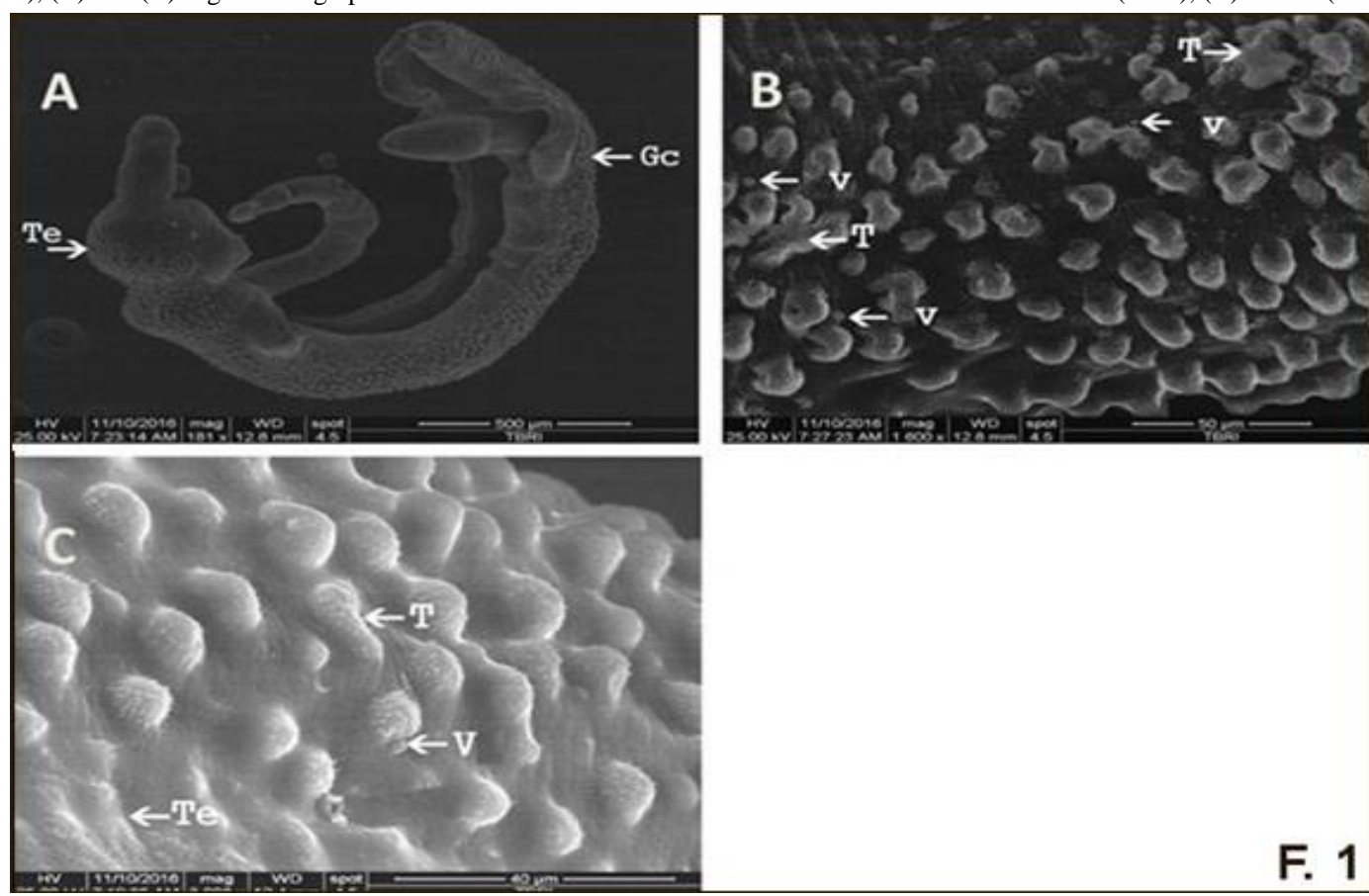

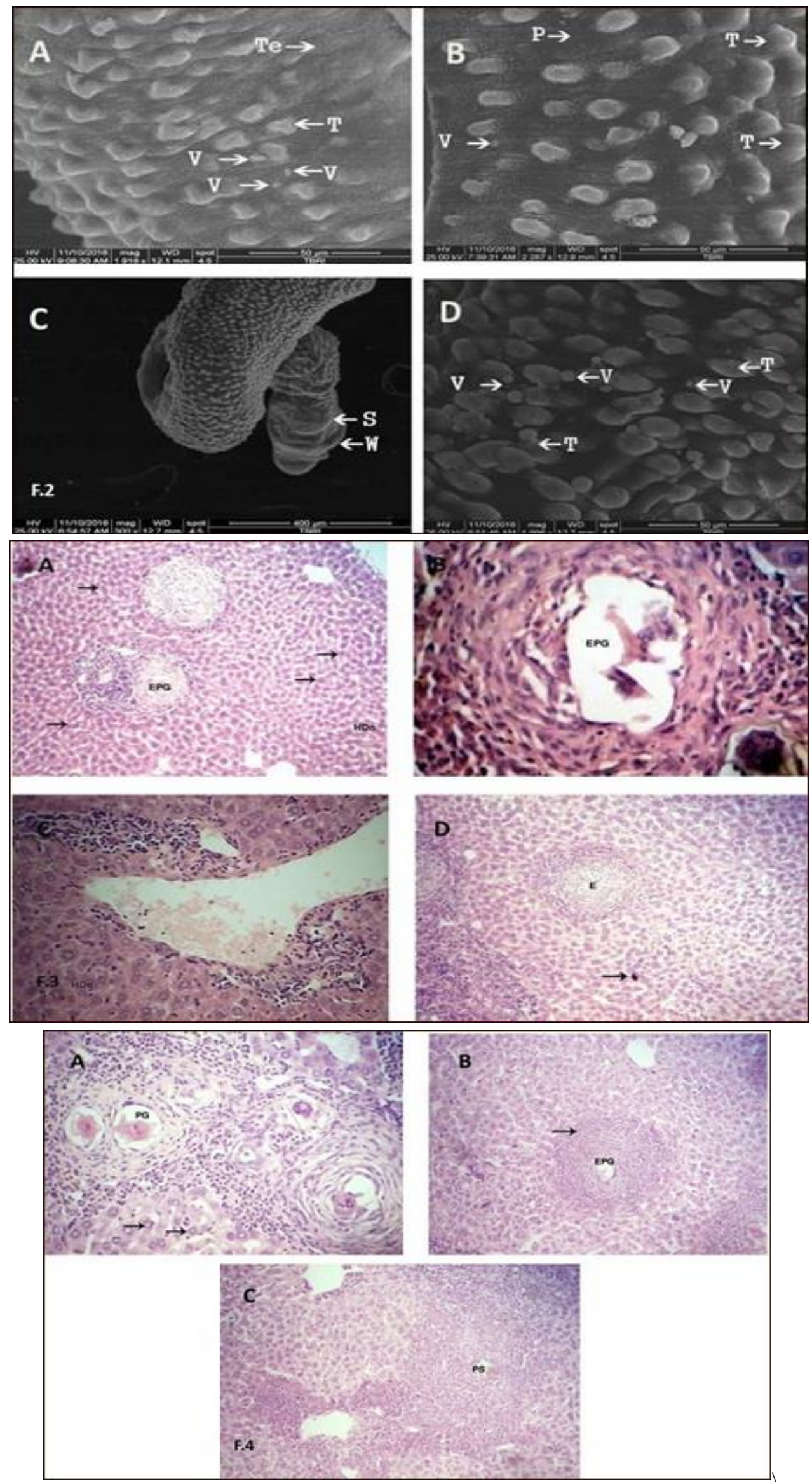